\title{
Physarum polycephalum haemagglutinins: effect of nutrition on synthesis, and their possible role in nature
}

\author{
Masashi Morita, Emiko Minami, Lei Zheng and Arasuke Nishi
}

Author for correspondence: Masashi Morita. Tel: +81764342281 ext. 2636. Fax: +81 764344656 .

Faculty of Pharmaceutical Sciences, Toyama Medical and Pharmaceutical University, Sugitani, Toyama 930-01, Japan

\begin{abstract}
The activity of haemagglutinins in plasmodia of Physarum polycephalum was measured under different culture conditions. The activity was markedly increased when the plasmodia were incubated in a non-nutrient salt medium. During starvation, significant amounts of haemagglutinins were found in the slime layer on the surface of the plasmodia. An increase in activity was not observed in the presence of actinomycin D or cycloheximide. Under starvation conditions, plasmodia are known to differentiate into either sclerotia (spherules) or fruiting bodies. Acceleration of haemagglutinin synthesis, however, was not always observed during spherulation and fruiting-body formation. Attempts to detect endogenous glycoconjugates that bind to the haemagglutinins were unsuccessful but we found that the haemagglutinins could bind to acidic polysaccharides produced by Escherichia coli K12. The bacterial glycoconjugates were purified and partially characterized. They contained $\mathbf{N}$-acetylhexosamine residues which appeared to be important for binding with the haemagglutinins. It is possible that the haemagglutinins play a physiological role in the interaction with these organisms.
\end{abstract}

Keywords: haemagglutinin, Physarum polycephalum, sclerotium (spherule)

\section{INTRODUCTION}

A number of lectins are distributed in many species of organisms ranging from bacteria to higher animals. The ability of lectins to bind specific glycoconjugates is of great interest in physiological cellular events and many plant lectins have been used as tools to distinguish saccharide structures on tumour cells, human blood cells or bacteria (Lis \& Sharon, 1986). In fungi, many lectins have been identified and characterized, but the physiological role of these lectins remains unclear. Ishikawa \& Oishi (1989) found that the lectins in Neurospora sitophila interact with $\mathrm{O}$-glycosidic glycoconjugates in their wall proteoglycans and suggested that they participate in cell wall biosynthesis. In Dictyostelium discoideum, lectins termed discoidin I and II have been studied in detail (Barondes \& Springer, 1987). The carbohydrate-binding sites of discoidin I interact with bacterial glycoconjugates and are thought to function in the compartmentalization of this protein in multilamellar bodies and its secretion from the cells in these packets (Barondes et al., 1985; Cooper et al., 1986), while cell-binding sites of the lectin

Abbreviation: $\mathrm{HAl}$, haemagglutination inhibitor. function in cell-substratum attachment and ordered cell migration (Springer et al., 1984). On the other hand, discoidin II, which becomes prominent in the later phase of development, is thought to have a role in spore coat formation (Cooper et al., 1983).

Physarum polycephalum, a true slime mould, shows several discrete phases in its life cycle (Sauer, 1982). Myxamoebae fuse in pairs and form a multi-nucleate plasmodium. Plasmodium is a naked mass of protoplasm surrounded by mucus polysaccharides which grows until nutrients are consumed. As a response to unfavourable conditions, such as starvation, plasmodia differentiate into either sclerotia (spherules) or fruiting bodies, depending on the light conditions (Schreckenbach et al., 1981).

Recently, we isolated soluble haemagglutinins termed haemagglutinins I and II from the plasmodia of $P$. polycephalum, each of which have a molecular mass of 6 and $11 \mathrm{kDa}$, respectively (Morita \& Nishi, 1992). Their haemagglutinating activities were inhibited by certain glycoproteins such as thyroglobulin but not by various monosaccharides and homopolysaccharides. Most of them existed in the intracellular soluble fraction of plasmodia but, after maximal growth, a significant amount of these proteins appeared in the slime layer on the 
plasmodial surface. In this paper, our attention was focused on the change in haemagglutinating activity in different phases of this organism, and the paper also reports the interaction of these haemagglutinins with bacterial glycoconjugates.

\section{METHODS}

Cultivation of P. polycephalum. Microplasmodia of $P$. polycephalum were grown in a semi-defined medium, containing glucose, yeast extract and tryptone, with shaking (Daniel \& Baldwin, 1964). The axenic cultures were maintained in $100 \mathrm{ml}$ liquid medium at $26^{\circ} \mathrm{C}$ in the dark. In some experiments, microplasmodia were incubated in a synthetic medium (Daniel \& Baldwin, 1964; Morita \& Nishi, 1993) or a non-nutrient salt medium (Polanshek et al., 1978) which contained $0.04 \mathrm{~g} \mathrm{HCl}$, $0.059 \mathrm{~g} \quad \mathrm{FeCl}_{2} .4 \mathrm{H}_{2} \mathrm{O}, \quad 0.082 \mathrm{~g} \mathrm{MnCl}_{2} .4 \mathrm{H}_{2} \mathrm{O}, \quad 0.033 \mathrm{~g}$ $\mathrm{ZnSO}_{4} .7 \mathrm{H}_{2} \mathrm{O}, 3.96 \mathrm{~g}$ citric acid, $1.18 \mathrm{~g} \mathrm{CaCl}_{2} .2 \mathrm{H}_{2} \mathrm{O}, 0.59 \mathrm{~g}$ $\mathrm{MgSO}_{4} \cdot 7 \mathrm{H}_{2} \mathrm{O}$ and $0.39 \mathrm{~g} \mathrm{KH}_{2} \mathrm{PO}_{4}$ per litre. Spherulation was induced by transferring microplasmodia to a semi-defined medium containing 0.5 M mannitol (Chet \& Rusch, 1969).

Cultivation of myxamoebae was carried out according to the method of Dee \& Anderson (1984). Stock cultures of the myxamoebae were maintained in a two-member culture with Escherichia coli in the dark at $26^{\circ} \mathrm{C}$. The myxamoebae were cultured on SM-1 agar plates $(7 \mathrm{~cm} \times 7 \mathrm{~cm})$ with $0.1 \mathrm{ml}$ live bacteria (about $1.6 \times 10^{7}$ cells $\mathrm{ml}^{-1}$ ). Plates became confluent within 3-4 d. The amoebae were harvested from the agar plate by washing them with $10 \mathrm{mM}$ sodium phosphate buffer $(\mathrm{pH}$ 6.4). The amoebae were collected by centrifugation at $1500 \mathrm{~g}$ for $15 \mathrm{~min}$ and washed repeatedly with the same buffer to remove bacteria. SM-1 medium contained $0.7 \mathrm{~g}$ tryptone, $0.2 \mathrm{~g}$ yeast extract, $0.6 \mathrm{~g}$ glucose, $0.8 \mathrm{~g} \mathrm{NaH}_{2} \mathrm{PO}_{4} .2 \mathrm{H}_{2} \mathrm{O}, 0.7 \mathrm{~g} \mathrm{Na}_{2} \mathrm{HPO}_{4}$ and $10.7 \mathrm{~g}$ agar (l distilled water) ${ }^{-1}$.

Cultivation of bacteria. E. coli, Klebsiella pneumoniae, Stapbylococcus aureus and Bacillus subtilis were cultured in Luria-Bertani (LB) medium with shaking at $37^{\circ} \mathrm{C}$ and Salmonella typhimurium was grown in nutrient broth (Difco). In some experiments, bacteria were cultured in M9 minimal medium (Maniatis et al., 1982). The number of viable bacteria cells was monitored by plating diluted bacterial cultures on LB-agar plates.

Induction of sporangia formation. Induction of sporangia formation was carried out according to the method of Daniel \& Rusch (1962) with some modifications (Morita et al., 1992). Microplasmodia were allowed to fuse and grown as macroplasmodia on oatmeal-agar plates. After $3 \mathrm{~d}$, the cultures were transferred onto a sporulation medium containing inorganic salts and niacin. They were further cultured for $2 \mathrm{~d}$ in the dark. Sporulation was induced by exposure of the starved plasmodia to white fluorescent lamps for $12 \mathrm{~h}$. Mature sporangia were observed 11-12 $\mathrm{h}$ after the end of illumination.

Purification of haemagglutinins. Plasmodial haemagglutinins were purified from the intracellular soluble fraction by successive chromatography using affinity, ion-exchange and hydroxylapatite columns as described previously (Morita \& Nishi, 1991).

Haemagglutinating assay. Plasmodia and myxamoebae were harvested and ruptured in PBS $(75 \mathrm{mM} \mathrm{NaCl}, 75 \mathrm{mM}$ $\mathrm{Na}_{2} \mathrm{HPO}_{4} / \mathrm{KH}_{2} \mathrm{PO}_{4}, \mathrm{pH} 7 \cdot 2$ ) with a Teflon homogenizer. The supernatant was obtained by centrifugation at $15000 \mathrm{~g}$ for 15 min. Haemagglutinating activity was measured with trypsintreated, formalin-fixed rabbit erythrocytes by a serial twofold dilution method with microtitre V-plates as described previously (Morita \& Nishi, 1991).
Haemagglutination inhibitor (HAl) assay. Glycoconjugates to be tested were dissolved in $0.15 \mathrm{M} \mathrm{NaCl}$ at appropriate concentrations. The solutions $(25 \mu \mathrm{l})$ were mixed with $25 \mu \mathrm{l}$ haemagglutinin solution in PBS containing four minimum haemagglutinating doses. Unless stated otherwise, partially purified haemagglutinin which contained both haemagglutinin I and II was used in this assay. After incubation for $30 \mathrm{~min}$ at room temperature, $25 \mu$ l trypsin-treated, formalin-fixed rabbit erythrocyte suspension $(3 \%, v / v)$ was added to the mixture to test the haemagglutinating activity. Inhibition activity was expressed as the minimum amount of carbohydrate required for $100 \%$ inhibition. Lipopolysaccharide (from E. coli), 2-keto-3deoxyocturonic acid, $N$-acetylglucosamine-3-sulfate and dextran sulfate were purchased from Sigma. The acid mucopolysaccharide kit, $N$-acetylgalactosamine, ethylene glycol chitin, xylane and chitooligosaccharide were purchased from Seikagaku Kogyo, and $\mathrm{N}$-acetyllactosamine from Dextra laboratories.

Purification of HAl. E. coli K12 cells cultured in M9 liquid medium were harvested by centrifugation at $15000 \mathrm{~g}$ for $15 \mathrm{~min}$ at $4{ }^{\circ} \mathrm{C}$. The suspension was filtered with a MF-Millipore filter ( $0.45 \mu \mathrm{m}$ pore-size, Millipore) to remove cell debris. The filtrate was concentrated by ultrafiltration (XM 300, Amicon), and solid urea was added to the solution to give a final concentration of $8 \mathrm{M}$, which improved the recovery of HAI. The mixture ( 9 $\mathrm{ml})$ was then applied on a gel-filtration column $(1.7 \times 92 \mathrm{~cm}$, Tosoh) of Toyopearl HW-65 equilibrated with $20 \mathrm{mM}$ Tris/ $\mathrm{HCl}, \mathrm{pH} 8.0$, containing $4 \mathrm{M}$ urea. Fractions of $4.5 \mathrm{ml}$ were collected. A portion of each fraction was removed to measure $A_{280}$. Sugar content was determined by the phenol/sulphuric acid method using glucose as standard, and the HAI activity was measured as above.

The active fractions were collected and applied on an ionexchange column $(0.8 \times 10.5 \mathrm{~cm}$, Pharmacia $)$ of DEAE-Sepharose CL-6B equilibrated with the same buffer. The adsorbed materials were eluted with a linear gradient of $0-1 \mathrm{M} \mathrm{NaCl}$ in the same buffer. Fractions of $3 \mathrm{ml}$ were collected. The active fractions were collected and dialysed against the same buffer for 24 h at $4{ }^{\circ} \mathrm{C}$. The dialysate was re-chromatographed on the same column. Fractions of $1.5 \mathrm{ml}$ were collected.

Periodate oxidation. This was performed according to the method of Green et al. (1985). About $5 \mathrm{mg}$ glucose equivalent $\mathrm{ml}^{-1}$ of bacterial saccharides was dissolved in $0.05 \mathrm{M}$ sodium acetate buffer ( $\mathrm{pH} 4.6$ ) containing $0.05 \mathrm{M}$ sodium metaperiodate. The mixture was incubated in the dark at $4{ }^{\circ} \mathrm{C}$ for $24 \mathrm{~h}$. The reaction was stopped by the addition of an excess amount of ethylene glycol.

Enzyme digestion. Glycoconjugates to be tested were dissolved in $0.1 \mathrm{M}$ Tris $/ \mathrm{HCl}(\mathrm{pH} \mathrm{8.3)}$ at a final concentration of $250 \mu \mathrm{g}$ glucose equivalent $\mathrm{ml}^{-1}$. Lysozyme $(60 \mu \mathrm{g})$ (egg white, Seikagaku Kogyo) was added to the suspension $(600 \mu \mathrm{l})$ and incubated at $37^{\circ} \mathrm{C}$ for $24 \mathrm{~h}$ under a toluene atmosphere. The reaction was terminated by boiling for $3 \mathrm{~min}$. $\beta$ - $N$-Acetylglucosaminidase (Jack bean, Seikagaku Kogyo) digestion was performed with $10 \mathrm{U}$ enzyme in $300 \mu \mathrm{l} 0.1 \mathrm{M}$ phosphate/citrate buffer $\left(\mathrm{pH} 5.0\right.$ ) at $37^{\circ} \mathrm{C}$ for $24 \mathrm{~h}$. Actinase E digestion was performed as follows. Glycoconjugates were suspended in $50 \mu \mathrm{l}$ $0 \cdot 1 \mathrm{M}$ ammonium carbonate and the suspension was incubated with $500 \mu \mathrm{g}$ actinase E (Kaken Chemical) at $37^{\circ} \mathrm{C}$ for $24 \mathrm{~h}$. Another $250 \mu \mathrm{g}$ actinase $\mathrm{E}$ was added to the suspension after $24 \mathrm{~h}$, and another at $48 \mathrm{~h}$. After $72 \mathrm{~h}$ of incubation, the reaction was terminated by boiling for $5 \mathrm{~min}$.

PAGE. The purified glycoconjugates were electrophoresed on agarose-containing polyacrylamide gels according to the method of Carney (1986) as described in a previous paper 
(Morita \& Nishi, 1991). The gel was polymerized with $1 \cdot 2 \%$ $(\mathrm{w} / \mathrm{v})$ acrylamide and $0.6 \%(\mathrm{w} / \mathrm{v})$ agarose. After electrophoresis, the gel was stained with toluidine blue.

Paper chromatography and TLC. All procedures were performed as described by Carney (1986). The purified polysaccharide (2-3 mg) was suspended in 100--250 $\mu \mathrm{l} 2 \mathrm{M} \mathrm{HCl}$. The air was replaced by $\mathrm{N}_{2}$ gas and the mixture heated at $100{ }^{\circ} \mathrm{C}$ for $4 \mathrm{~h}$ in a screw-capped tube. The hydrolysate was fractionated by descending-paper chromatography for $25 \mathrm{~h}$ on Whatman no. 1 paper in a solvent system of $n$-butanol/pyridine/water $10: 3: 3$, by vol.). After development, sugars were revealed by the alkaline silver nitrate method. Glucose, galactose, mannose, fucose and rhamnose were used as standards and spotted on the same paper. In another experiment, the hydrolysate was spotted on a cellulose-coated TLC plate (Merck) and developed in a solvent system of $n$-butanol/pyridine $/ 0 \cdot 1 \mathrm{M} \mathrm{HCl}(5: 3: 2$, by vol.). Spots of aldoses, ketoses and oligosaccharides were detected by spraying with a reagent which contained diphenylamine, aniline and phosphoric acid in acetone. Glucose, galactose, mannose, fucose, glucosamine and galactosamine were used as standards.

Protein assay. Protein concentration was estimated by the Lowry method using BSA as standard.

\section{RESULTS}

\section{Changes in haemagglutinating activity in different media}

Our previous work demonstrated that microplasmodia of $P$. polycephalum produce two soluble haemagglutinins, haemagglutinins I and II (Morita \& Nishi, 1992). Most of the haemagglutinins were found in the intracellular soluble fraction, though small amounts of them were associated with the slime layer on the plasmodial surface. The haemagglutinating activity of plasmodia grown in a semi-defined medium was about 100 titre $^{-1}$ (mg plasmodial protein $)^{-1}$ (Table 1). When the plasmodia were

\section{Table 1. Changes in haemagglutinating activity of $P$. polycephalum grown in different media}

Microplasmodia grown in a semi-defined medium were harvested and transferred into various media. After incubation for $48 \mathrm{~h}$, plasmodia were collected by centrifugation and disrupted by sonic oscillation. The homogenates were centrifuged at $15000 \mathrm{~g}$ for $15 \mathrm{~min}$, and the haemagglutinating activities of the supernatants were assayed with trypsin-treated, formalin-fixed rabbit erythrocytes as outlined in Methods. The activity was determined by a serial twofold dilution method and expressed as titre $^{-1}$ (mg plasmodial protein $)^{-1}$.

\begin{tabular}{|lcc|}
\hline Medium & \multicolumn{2}{c|}{$\begin{array}{c}\text { Haemagglutinating } \\
\text { activity }\end{array}$} \\
\cline { 2 - 3 } & $\begin{array}{c}\text { [Titre } \\
\text { [1 } \\
\end{array}$ & \\
\hline (mg protein) $\left.)^{-1}\right]$ & Ratio \\
Semi-defined & $100 \pm 33$ & 1 \\
Glucose-free semi-defined & $322 \pm 69$ & 3 \\
Synthetic & $410 \pm 150$ & 4 \\
Non-nutrient salt & $1078 \pm 106$ & 11 \\
\hline
\end{tabular}

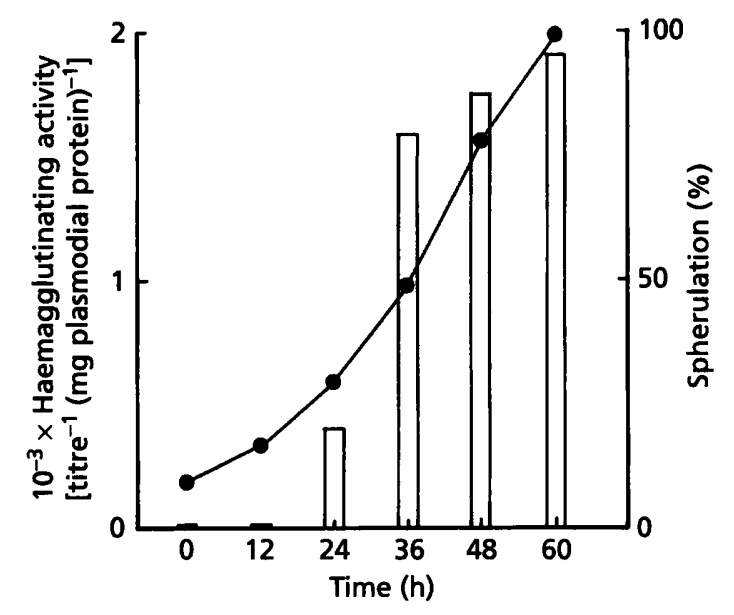

Fig. 1. Changes in haemagglutinating activity during starvation and spherulation. Plasmodia grown in semi-defined medium were transferred into non-nutrient salt medium and incubated to induce spherulation. Aliquots of the culture were removed at the time indicated, and the haemagglutinating activity (O) in the cell homogenate was measured as in Table 1 . The rate of spherulation (open bar) was measured under a microscope after fixing with glutaraldehyde.

cultured in the semi-defined medium lacking glucose or in a complete synthetic medium, a three- to fourfold increase in the activity was generally observed. As described previously (Morita \& Nishi, 1993), the doubling times for plasmodial growth in the semi-defined, glucose-free semidefined and synthetic media were about $9 \mathrm{~h}, 14 \mathrm{~h}$ and $30 \mathrm{~h}$, respectively. The activity (mg plasmodial protein) ${ }^{-1}$ appeared to increase when the plasmodia were cultured in nutrient-poor media. As the synthetic medium contains glucose and various amino acids, the production of haemagglutinins might not be controlled by glucose catabolites. When the plasmodia grown in the synthetic medium were transferred into the same medium lacking glucose or an amino acid mixture, about a three- or fivefold increase of the activity was observed after $48 \mathrm{~h}$, respectively. As expected, the highest activity [1078 titre ${ }^{-1}$ $(\mathrm{mg} \text { protein })^{-1}$ ] was observed when the plasmodia were incubated in a non-nutrient salt medium.

Increase of the activity was inhibited by adding cycloheximide $\left(30 \mu \mathrm{g} \mathrm{ml}^{-1}\right)$ or actinomycin D $\left(200 \mu \mathrm{g} \mathrm{ml}^{-1}\right)$, suggesting that de novo protein and RNA syntheses were required for haemagglutinin synthesis (data not shown).

\section{Haemagglutinating activity during spherule and fruiting-body formation}

Plasmodia grown in a non-nutrient salt medium are destined to differentiate into spherules in the dark. More than $90 \%$ of the plasmodia were transformed into the structure characteristic of spherules within $48 \mathrm{~h}$. Concomitantly with the spherulation, a marked increase in the haemagglutinating activity was observed (Fig. 1). It is therefore possible that the haemagglutinins may participate in the morphological changes. To test this, 
Table 2. Effect of $0.5 \mathrm{M}$ mannitol on haemagglutinating activity

Plasmodia grown in a semi-defined medium were transferred into the same medium in the absence or presence of $0.5 \mathrm{M}$ mannitol, or into non-nutrient salt medium. Haemagglutinating activity was measured after $48 \mathrm{~h}$.

\begin{tabular}{|c|c|c|c|}
\hline \multirow[t]{2}{*}{ Medium } & \multicolumn{2}{|c|}{$\begin{array}{l}\text { Haemagglutinating } \\
\text { activity }\end{array}$} & \multirow[t]{2}{*}{$\begin{array}{c}\text { Spherulation } \\
(\%)\end{array}$} \\
\hline & $\begin{array}{c}\text { [Titre }^{-1} \\
\left.(\mathrm{mg} \text { protein })^{-1}\right]\end{array}$ & Ratio & \\
\hline Semi-defined & $128 \pm 5$ & $1 \cdot 0$ & 0 \\
\hline $\begin{array}{l}\text { Semi-defined } \\
+0.5 \mathrm{M} \\
\text { mannitol }\end{array}$ & $144 \pm 9$ & $1 \cdot 1$ & 50 \\
\hline $\begin{array}{l}\text { Non-nutrient } \\
\text { salt }\end{array}$ & $1739 \pm 107$ & $13 \cdot 6$ & 90 \\
\hline
\end{tabular}

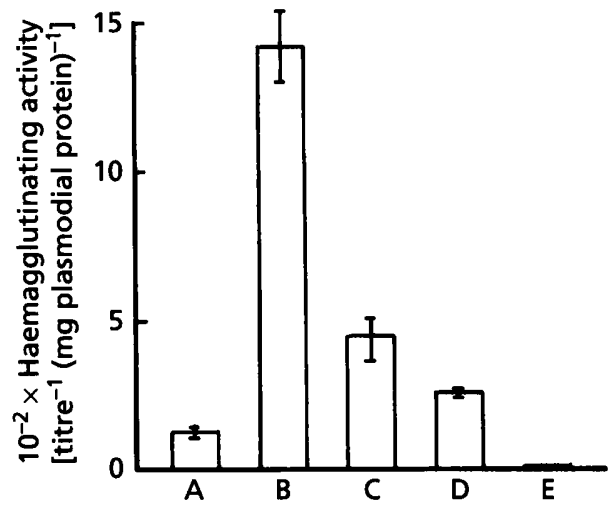

Fig. 2. Changes in haemagglutinating activity during fruitingbody formation. Microplasmodia were pipetted onto a MFMillipore filter on an oatmeal agar medium and cultured in the dark (growth phase; A). After $48 \mathrm{~h}$, the plasmodia were transferred onto a sporulation agar medium and starved for $\mathbf{2 d}$ in the dark (starvation phase; B). Fruiting body formation was induced by exposure of the plasmodia to the light for $12 \mathrm{~h}$ (fruiting body formation phase; C). Complete fruiting bodies (D) were harvested $12 \mathrm{~h}$ after the end of illumination. Myxamoebae (E) from $P$. polycephalum were cultured on an agar plate with live $E$. coli in the dark at $26^{\circ} \mathrm{C}$. The amoebae were scraped from the plate and separated from bacteria by repeated centrifugation at $1500 \mathrm{~g}$ for $15 \mathrm{~min}$. After homogenization, the cells were centrifuged and the haemagglutinating activity in the supernatant was measured.

spherulation was induced by incubating microplasmodia in the semi-defined medium containing $0.5 \mathrm{M}$ mannitol, in which plasmodia likewise differentiated into spherules without starvation (Chet \& Rusch, 1969). After incubation for $48 \mathrm{~h}$, spherulation was observed in about $50 \%$ of the plasmodia and, at that time, the haemagglutinating activity was about 144 titre $^{-1}$ (mg protein) ${ }^{-1}$ (Table 2 ). This activity was significantly less than that of plasmodia cultured in the non-nutrient salt medium [1739 titre $^{-1}$ (mg protein $)^{-1}$. These results suggest that spherulation was not necessarily accompanied by an increase of the haemagglutinating activity.

Fig. 2 shows the activity during fruiting-body formation. The haemagglutinating activity in growing plasmodia was about 124 titre $^{-1}$ (mg protein $)^{-1}$, which was increased up to 1424 titre $^{-1}$ (mg protein) ${ }^{-1}$ after $2 \mathrm{~d}$ starvation. Once plasmodia became differentiated into fruiting bodies, the activity was gradually decreased [448 titre ${ }^{-1}$ (mg protein $)^{-1}$ at young fruiting bodies], though an appreciable amount of the haemagglutinating activity still remained in the mature fruiting bodies $\left[255\right.$ titre $^{-1}(\mathrm{mg}$ protein $)^{-1}$. It is questionable, however, whether or not the spores in the sporangia contain haemagglutinins because no detectable haemagglutinating activity was found in myxamoebae. Myxamoebae did not show any haemagglutinating activities even when they were cocultivated with a bacterium lacking HAI activity. It thus appears that the production of haemagglutinins is characteristically related to the plasmodial phase and is induced by starvation.

\section{Glycoconjugates that bind to haemagglutinin}

In an attempt to clarify the physiological role of the haemagglutinins, various cell fractions of the slime mould were examined for their haemagglutinin-binding activity. Endogenous glycoproteins or polysaccharides, in some cases, serve as the natural ligands of carbohydrate-binding proteins. Lectins in the multicellular slime moulds $D$. discoideum and Polysphondylium pallidum were reported to bind to membrane or wall-associated glycoconjugates (Cooper et al., 1983; Drake \& Rosen, 1982). Our previous reports showed that the plasmodial surface of $P$. polycephalum is also rich in glycoconjugates (Kuroda et al., 1989; Morita et al., 1986; Morita \& Nishi, 1989). However, preliminary studies indicated that none of the cellular fractions including the slime substance (McCormic et al., 1970a), plasma membrane (Kuroda et al., 1989), spherule wall (Zaar et al., 1979) and spore coat (McCormic et al., 1970b) inhibit the haemagglutinating activity (data not shown).

Binding of the haemagglutinins to microbial glycoconjugates was also examined by measuring HAI activity. Bacteria grown in LB medium were pelleted by centrifugation and resuspended in $\mathrm{H}_{2} \mathrm{O}$. The suspension was boiled for $1 \mathrm{~h}$ and supernatant was used as boiled extract for the HAI assay. High HAI activity was found in the boiled extract from E. coli K12. The minimum cell number inhibiting four haemagglutinating doses was $2 \times 10^{9}$ cells. In contrast, the activity from other bacteria such as $K$. pneumoniae, $S$. aureus, $B$. subtilis and $S$. typhimurium, was negligible even at $7 \times 10^{10}, 2 \times 10^{11}$, $4 \times 10^{10}$ and $2 \times 10^{10}$ cells, respectively. However, very low HAI activity was sometimes observed in the culture fluid of the latter three bacteria when they were incubated in M9 minimal medium (data not shown). The HAI activity from $E$. coli $\mathrm{K} 12$ was resistant to exhaustive proteolytic digestion with actinase $\mathrm{E}$ but completely 

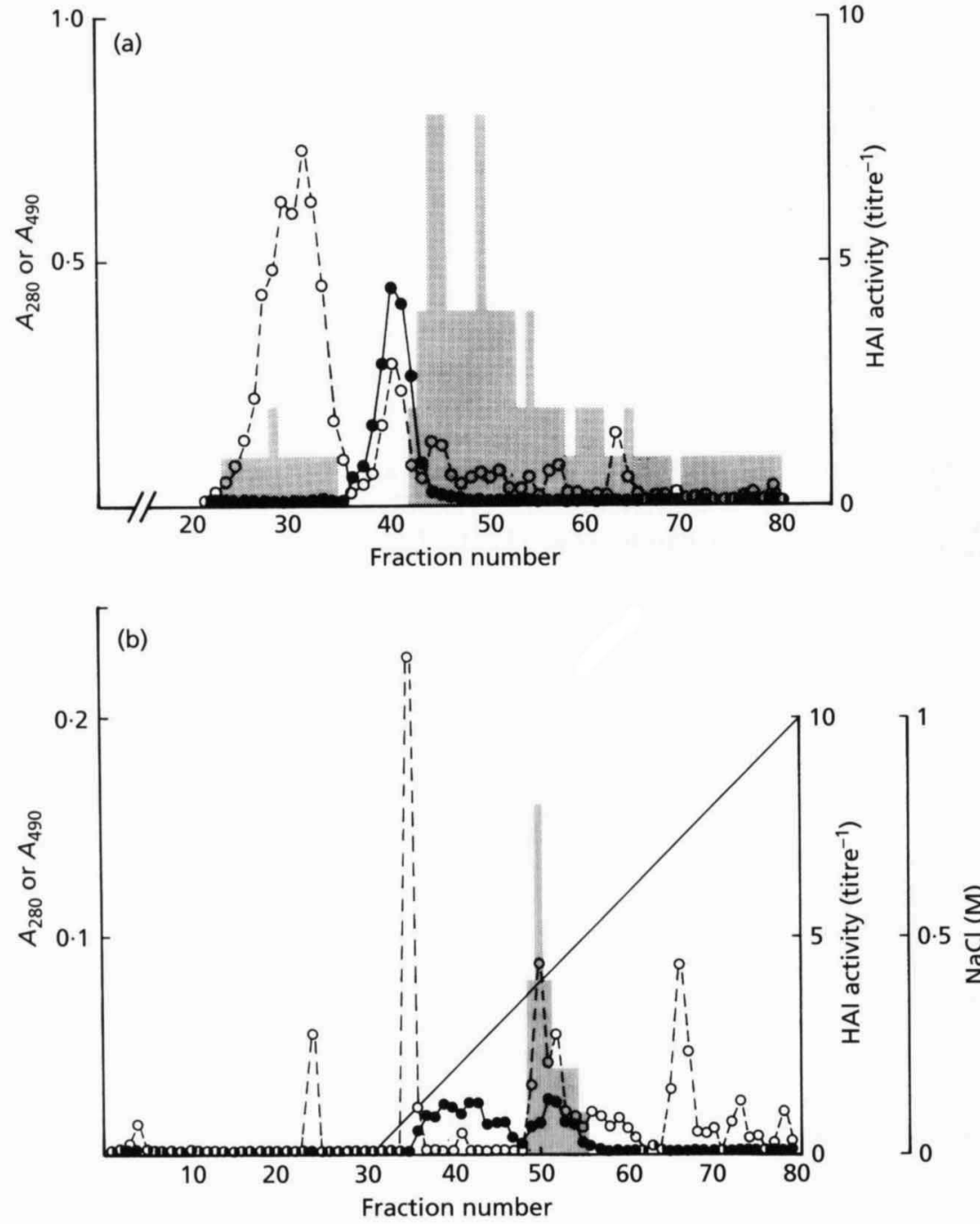

Fig. 3. Purification of $E$. coli K12 polysaccharides with HAl activity by column chromatography. (a) Gel-filtration chromatography of polysaccharides from $E$. coli K12. E. coli $K 12$ was cultured in $M 9$ medium, and the extracellular fluid was obtained by centrifugation. The supernatant was filtered through a MF-Millipore filter $(0.45 \mu \mathrm{m}$ pore-size) to remove cell debris, and solid urea was added to the solution to give a final concentration of $8 \mathrm{M}$. This solution was then applied onto a Toyopearl HW-65 column (Tosoh, $1.7 \times 92 \mathrm{~cm}$ ), and the column was eluted with $20 \mathrm{mM}$ Tris/ $\mathrm{HCl}(\mathrm{pH}$ 8.0) containing $4 \mathrm{M}$ urea (4.5 $\mathrm{ml}$ fractions). Each fraction was assayed for $\mathrm{HAl}$ activity (shaded bar), protein (O, $A_{280}$ ) and sugar (O, phenol/sulfuric acid method measured at $\left.A_{490}\right)$. Standard proteins, thyroglobulin (669 kDa) and carbonic anhydrase $(29 \mathrm{kDa})$, were eluted at fraction nos 23 and 67 , respectively. (b) DEAE-Sepharose column chromatography of polysaccharides from $E$. coli $\mathrm{K} 12$. The active fractions (nos 43-52) in (a) were collected and applied onto a DEAESepharose CL-6B column (Pharmacia, $0.8 \times 10.5 \mathrm{~cm})$. The materials were eluted with a linear gradient of $0-1 \mathrm{M} \mathrm{NaCl}$. The active fractions (nos 49-55) were combined and dialysed, and they were chromatographed on the same column for further purification (data not shown). destroyed by periodate oxidation, suggesting that the essential structure in HAI from E. coli $\mathrm{K} 12$ contained a polysaccharide moiety. The molecular mass was more than $300 \mathrm{kDa}$ as judged by gel-filtration on Toyopearl HW-75. When E. coli $\mathrm{K} 12$ was cultured in $\mathrm{M} 9$ minimal medium, more than $95 \%$ of the HAI activity was found in an extracellular fraction. The HAI activity was easily released from $E$. coli $\mathrm{K} 12$ cells by boiling with $\mathrm{H}_{2} \mathrm{O}$, suggesting that the HAI is not integral but is a peripheral component of the bacterial cell wall. Until now, however, our efforts to detect HAI activity in the known constituents of bacterial extracellular and wall polysaccharides have been unsuccessful. These compounds include lipopolysaccharide, 2-keto-3-deoxyocturonate, teichoic acid, xylan, dextran sulfate, $N$-acetylmuramic acid (at $\left.5 \mathrm{mg} \mathrm{ml}^{-1}\right), \quad N$-acetylglucosamine, $N$-acetylgalactosamine, glucose, galactose, fucose, rhamnose and glucuronic acid (at $0.2 \mathrm{M}$ ). Preliminary experiments also indicated that plasmodial haemagglutinins neither aggregate $E$. coli $\mathrm{K} 12$ cells nor influence the bacterial growth at the concentration which caused complete agglutination of rabbit erythrocytes.

\section{Some properties of glycoconjugates with HAl activity}

The HAI activity of polysaccharides from E. coli $K 12$ disappeared after the treatment with $\beta$ - $N$-acetylglucosaminidase. This result suggested that the oligosaccharide structure contains terminal $\beta$-linked $N$-acetylhexosamine residues required for binding to the haemagglutinins. Similar results were obtained when thyroglobulin, which is a potent HAI, was subjected to mild acid treatment followed by $\beta-N$-acetylglucosaminidase digestion. Digestion of the asialo-thyroglobulin with this enzyme resulted in a complete disappearance of its capacity to inhibit the haemagglutinating activity. However, none of the other glycoconjugates hitherto tested, such as chitooligosaccharide $\quad\left(10 \mathrm{mg} \mathrm{ml}^{-1}\right), \quad N$-acetyllactosamine (5 $\left.\mathrm{mg} \mathrm{m}^{-1}\right), N$-acetylglucosamine-3-sulfate $\left(10 \mathrm{mg} \mathrm{ml}^{-1}\right)$ or ethylene glycol chitin $\left(10 \mathrm{mg} \mathrm{ml}^{-1}\right)$, showed any detectable HAI activity.

The HAI activity of the polysaccharides from E. coli $K 12$ markedly reduced $(25 \%)$ after the digestion with lysozyme, supporting the view that the HAI may be associated with cell wall polysaccharides. To characterize it in more 


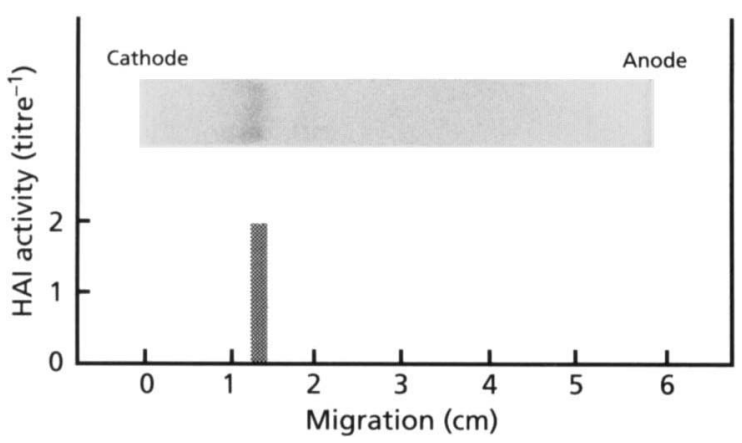

Fig. 4. Electrophoretogram of the purified inhibitor on a polyacrylamide gel containing agarose. $\mathrm{HAl}$ purified from the culture fluid of $E$. coli $\mathrm{K} 12$ was dissolved in $10 \mathrm{mM}$ Tris-acetate (pH 6.8) containing $0.25 \mathrm{mM}$ sodium sulfate and about $5 \mu \mathrm{g}$ glucose equivalent of the inhibitor was loaded on the gel. After the electrophoresis, the gel was stained with toluidine blue. The gel was cut into $3 \mathrm{~mm}$ strips and the HAl activity was extracted with $0.15 \mathrm{M} \mathrm{NaCl}$.

detail, we attempted to purify HAI from the culture fluid of E. coli $\mathrm{K} 12$ by column chromatography. As shown in Fig. 3(a), HAI activity appeared in diverse fractions after gel-filtration. The active fractions (fraction nos 43-52) were then applied on a column of DEAE-Sephacel (Fig. $3 \mathrm{~b})$. The ion-exchange chromatography was repeated once more. Based on the minimum amount ( $\mu \mathrm{g}$ glucose equivalent $\mathrm{ml}^{-1}$ ) required to inhibit four haemagglutinin doses, the specific activity of the purified HAI $\left(0.8 \mu \mathrm{g} \mathrm{ml}^{-1}\right)$ was about fivefold higher than that of the culture fluid $\left(3.8 \mu \mathrm{g} \mathrm{ml}^{-1}\right)$. The purified HAI was a more potent inhibitor of plasmodial haemagglutinins than thyroglobulin $\left(6.8 \mu \mathrm{g} \mathrm{ml}^{-1}\right)$. Fig. 4 shows an electrophoretogram of purified HAI. It revealed that the band with HAI activity was positive to the toluidine blue staining suggesting that the active substance is an acidic carbohydrate. Digestion of HAI with actinase E did not affect the electrophoretic mobility. The results of paper chromatography and TLC indicated that the purified HAI was composed of $\mathrm{N}$-acetylglucosamine, $\mathrm{N}$-acetylgalactosamine, glucose and galactose.

\section{DISCUSSION}

In the present study, we found that haemagglutinin synthesis was markedly accelerated in plasmodia grown in nutrient-poor media, in which they are destined to differentiate into dormant forms called spherules or sclerotia. In Rbizoctonia solani, the lectin of the sclerotia was reported to serve as a storage protein in the resting structure of the fungus (Kellens \& Peumans, 1990) because it increased during sclerotia formation and disappeared after germination. In contrast, a similar result was not observed in P. polycephalum. It thus seems unlikely that plasmodial haemagglutinins are functioning as storage proteins in their dormant structures. However, it should be noted that the haemagglutinins were found only in the plasmodial stage (diploid) and not detected in myxamoebae (haploid). As with discoidin I and II, lectins produced by $D$. discoideum (Barondes \& Springer, 1987), the production of Pbysarum haemagglutinins is thought to be controlled in a developmentally regulated fashion.

High haemagglutinating activity in starved plasmodia suggested that the haemagglutinins function under particular environmental conditions in this organism. One approach to determine the functions of these haemagglutinins is to detect glycoconjugates which interact with them since the haemagglutinins may act by binding to such ligands. In $D$. discoideum, an endogenous lectin, discoidin I, has been thought to be involved in cellsubstratum attachment and ordered cell migration during aggregation. Discoidins were reported to bind to endogenous cell surface oligosaccharide with a structure Man $33(\operatorname{Man} \alpha 6)(\mathrm{Xyl}$ \%2)Man $\beta 4$ GlcNAc (AmatayakulChantler et al., 1991). Eitle et al. (1993) also reported the presence of lectins on the Dictyostelium cell surface which react with anionic polysaccharides. Drake \& Rosen (1982) have purified a sulfated glycoprotein from the membrane fraction of the cellular slime mould Pol. pallidum which was interacting with pallidin, a lectin in this mould. We have previously shown that plasmodial membrane proteins are generally glycosylated (Kuroda et al., 1989; Morita et al., 1986; Morita \& Nishi, 1989) and their surface is covered by a slime layer with haemagglutinating activity (Morita \& Nishi, 1991). It is possible, therefore, that some of these glycoconjugates may serve as endogenous ligands for plasmodial haemagglutinins. However, various plasmodial fractions did not show any detectable haemagglutinin-binding activity. A more sensitive assay method may be required for detecting the endogenous ligands of the haemagglutinins, if there are any. A search for endogenous glycoconjugates with HAI activity is still in progress in our laboratory.

In the natural environment, starving plasmodia migrate on a substratum in search for a nutrient such as fungi and bacteria. A lectin in R. solani hyphae was believed to play a role in the recognition and adherence of the mycoparasite Trichoderma (Elad et al., 1983; Inbar \& Chet, 1992). It has also been reported that capture of nematodes by the nematophagous fungus Arthrobotrys oligospora is mediated by a lectin on the fungal surface (Rosen $e t$ al., 1992). The haemagglutinins in the slime layer on migrating Pbysarum plasmodia may interact with polysaccharides derived from bacteria. The present study has shown that plasmodial haemagglutinins recognized wallassociated acidic polysaccharides from E. coli $\mathrm{K} 12$ and $N$ acetylhexosamine residues in their moiety are responsible for the binding. The HAI activity of the polysaccharide was eight times higher than that of thyroglobulin, suggesting the possibility that certain bacterial polysaccharides are the natural ligand of Pbysarum haemagglutinins. A number of lectins or some lectin-like proteins have been reported to be reactive with bacteria by binding mannans, teichoic acids or lipopolysaccharides (Pistole, 1981). The specificity of symbiotic association between Rbizobium and legumes would be determined by the host plant lectin because the plant lectin recognized lipopolysaccharides (Kalsi et al., 1992) or capsular polysaccharides (Calvert et al., 1978) on the Rbizobium cell 
surface. In some insects (Komano et al., 1980; Jomori \& Natori, 1992), a lectin-like protein in haemolymph was shown to be responsible for the process of phagocytosis. This lectin may bind to the glycoconjugates on foreign bacteria and facilitate ingestion of bacteria by haemocytes. It seems unlikely, however, that the plasmodial haemagglutinins have a role in the ingestion of bacteria by phagocytosis because we did not detect any haemagglutinating activity in myxamoebae, which also grow by ingesting bacteria. A similar result was also reported in $D$. discoideum. Although discoidin I is known to interact with bacterial polysaccharides, vegetative amoebae without the lectin activity can ingest bacteria by phagocytosis. At present, the fact that plasmodial haemagglutinins bind exclusively to glycoconjugates from $E$. coli $\mathrm{K} 12$ is very puzzling when considering the role of haemagglutinins in the intake of nutrition. The structural properties of capsules, however, vary between bacteria, and wall composition may be altered according to the growth conditions (Sutherland, 1985). Therefore, we do not rule out the possibility that various bacteria commonly possess the polysaccharides that bind to the haemagglutinins.

At present, it is difficult to explain the function of the Pbysarum haemagglutinins, but the present study suggested that their physiological roles in nature should be investigated. In order to elucidate the biological role of plasmodial haemagglutinins, an immunological investigation of relevant endogenous ligands is now in progress.

\section{REFERENCES}

Amatayakul-Chantler, S., Ferguson, M. A., Dwek, R. A., Rademacher, T. W., Parekh, R. B., Crandall, I. E. \& Newell, P. C. (1991). Cell surface oligosaccharides on Dictyostelium during development. J Cell Sci 99, 485-495.

Barondes, S. H. \& Springer, W. R. (1987). An endogenous lectin and an oligosaccharide participate in adhesion mechanisms in Dictyostelium. In Genetic Regulation of Development, pp. 129-140. Edited by W. F. Loomis. New York: Alan. R. Liss.

Barondes, S. H., Haywood-Reid, P. L. \& Cooper, D. N. W. (1985). Discoidin I, an endogenous lectin, is externalized from Dictyostelium discoideum in multilamellar bodies. J Cell Biol 100, 1825-1833.

Calvert, H. E., Lalonde, M., Bhuvaneswari, T. V. \& Bauer, W. D. (1978). Role of lectins in plant-microorganism interactions. IV. Ultrastructural localization of soybean lectin binding sites on Rhizobium japonicum. Can J Microbiol 24, 785-793.

Carney, S. L. (1986). Monosaccharides. In Carbobydrate Analysis, pp. 1-36. Edited by M. F. Chaplin \& J. F. Kennedy. Oxford \& Washington, DC: IRL Press.

Chet, I. \& Rusch, H. P. (1969). Induction of spherule formation in Pbysarum polycephalum by polyols. J Bacteriol 100, 673-678.

Cooper, D. N., Lee, S.-C. \& Barondes, S. H. (1983). Discoidinbinding polysaccharide from Dictyostelium discoideum. J Biol Chem 258, 8745-8750.

Cooper, D. N. W., Haywood-Reid, P. L., Springer, W. R. \& Barondes, S. H. (1986). Bacterial glycoconjugates are natural ligands for the carbohydrate binding site of discoidin $I$ and influence its cellular compartmentalization. Dev Biol 114, 416-425.

Daniel, J. W. \& Baldwin, H. H. (1964). Axenic culture of Pbysarum polycephalum on soluble media. Methods Cell Physiol 1, 15-29.

Daniel, J.W. \& Rusch, H. P. (1962). Methods for inducing sporulation of pure cultures of the myxomycete Pbysarum polycephalum. J Bacteriol 83, 234-240.

Dee, J. \& Anderson, R.W. (1984). The effect of ploidy on the stability of plasmodial heterokaryons in Pbysarum polycephalum. $J$ Gen Microbiol 131, 1167-1179.

Drake, D. K. \& Rosen, S. D. (1982). Identification and purification of an endogenous receptor for the lectin pallidin from Polysphondylium pallidum. J Cell Biol 93, 383-389.

Eitle, E., Keller, T., Parish, C. R. \& Parish, R. W. (1993). Polysaccharides influence the aggregation of Dictyostelium discoideum cells and bind to developmentally regulated cell surface proteins. Exp Cell Res 205, 374-382.

Elad, Y., Barak, R. \& Chet, I. (1983). Possible role of lectins in mycoparasitism. J Bacteriol 154, 1431-1435.

Green, E. D., van Halbeek, H., Boime, I. \& Baenziger, J. U. (1985). Structural elucidation of the disulfated oligosaccharide from bovine leutropin. J Biol Chem 260, 15623-15630.

Inbar, J. \& Chet, I. (1992). Biomimics of fungal cell-cell recognition by use of lectin-coated nylon fibers. J Bacteriol 174, 1055-1059.

Ishikawa, F. \& Oishi, K. (1989). Production, purification, and characterization of Neurospora sitophila lectin. Agric Biol Chem 53, 1769-1776.

Jomori, T. \& Natori, S. (1992). Function of the lipopolysaccharidebinding protein of Periplaneta americana as an opsonin. FEBS Lett 296, 283-286.

Kalsi, G., Das, H. R., Babu, C. R. \& Das, R. H. (1992). Isolation and characterization of a lectin from peanut roots. Biochim Biophys Acta 1117, 114-119.

Kellens, J. T. C. \& Peumans, W. J. (1990). Developmental accumulation of lectin in Rhizoctonia solani: a potential role as a storage protein. J Gen Microbiol 136, 2489-2495.

Komano, H., Mizuno, D. \& Natori, S. (1980). Purification of lectin induced in the hemolymph of Sarcophage peregrina larvae on injury. $J$ Biol Chem 255, 2919-2924.

Kuroda, T., Morita, M., Okai, K., Okamura, S. \& Nishi, A. (1989). Isolation of plasma membrane and analysis of membrane glycoproteins from the slime mould Physarum polycephalum.J Gen Microbiol 135, 873-881.

Lis, H. \& Sharon, N. (1986). Lectins as molecules and as tools. Annu Rev Biocbem 55, 35-67.

Maniatis, T., Fritsch, E. F. \& Sambrook, J. (1982). In Molecular Cloning: a Laboratory Manual, pp. 68-73. Cold Spring Harbor, NY: Cold Spring Harbor Laboratory.

McCormic, J. J., Blomquist, J. C. \& Rusch, H. P. (1970a). Isolation and characterization of a galactosamine wall from spores and spherules of Pbysarum polycepbalum. J Bacteriol 104, 1119-1125.

McCormic, J. J., Blomquist, J. C. \& Rusch, H. P. (1970b). Isolation and characterization of an extracellular polysaccharide from Physarum polycephalum. J Bacteriol 104, 1110-1118.

Morita, M. \& Nishi, A. (1989). Characterization of glycopeptides from Pbysarum polycephalum labelled with $\left[{ }^{3} \mathrm{H}\right]$ mannose or $\left[{ }^{3} \mathrm{H}\right]-$ glucosamine. J Gen Appl Microbiol 35, 413-427.

Morita, M. \& Nishi, A. (1991). Glycoproteins and enzymes associated with the plasmodial membrane and slime layer of Pbysarum polycepbalum. J Gen Appl Microbiol 37, 93-109.

Morita, M. \& Nishi, A. (1992). Isolation and partial characterization of haemagglutinins from plasmodia of Pbysarum polycephalum. J Gen Microbiol 138, 619-625.

Morita, M. \& Nishi, A. (1993). Purification and partial characterization of $\beta$-glucosidase from plasmodial membrane and culture medium of Physarum polycephalum. J Gen Microbiol 139, 1635-1641. 
Morita, M., Kurosaki, F. \& Nishi, A. (1986). Lipid-oligosaccharide intermediate of glycoprotein synthesis in Physarum polycephalum. Biocbim Biophys Acta 881, 148-153.

Morita, M., Murata, Y., Kaneko, Y., Matsushima, H. \& Nishi, A. (1992). Changes in membrane glycoproteins during fruit-body formation in Pbysarum polycephalum. Bot Mag Tokyo 105, 515-527.

Pistole, T. G. (1981). Interaction of bacteria and fungi with lectins and lectin-like substances. Annu Rev Biochem 35, 85-112.

Polanshek, M. M., Blomquist, J. C., Evans, T. E. \& Rusch, H. P. (1978). Aminopeptidase of Pbysarum polycephalum during growth and differentiation. Arch Biochem Biophys 190, 261-269.

Rosen, S., Ek, B., Rask, L. \& Tunlid, A. (1992). Purification and characterization of a surface lectin from the nematode-trapping fungus Artbrobotrys oligospora. J Gen Microbiol 138, 2662-2672.

Sauer, H. W. (1982). Developmental Biology of Physarum. Cambridge: Cambridge University Press.
Schreckenbach, T., Walckhoff, B. \& Verfuerth, C. (1981). Bluelight receptor in a white mutant of Physarum polycephalum mediates inhibition of spherulation and regulation of glucose metabolism. Proc Natl Acad Sci US A 78, 1009-1013.

Springer, W. R., Cooper, D. N. W. \& Barondes, S. H. (1984). Discoidin I is implicated in cell-substratum attachment and ordered cell migration of Dictyostelium discoideum and resembles fibronectin. Cell 39, 557-564.

Sutherland, I. W. (1985). Biosynthesis and composition of gramnegative bacterial extracellular and wall polysaccharides. Annu Rev Microbiol 39, 243-270.

Zaar, K., Beyer, P. \& Kleining, H. (1979). The spherule wall of Physarum polycephalum: chemical analysis and electron microscopy. Biochim Biophys Acta 582, 21-32.

Received 12 January 1995; revised 18 April 1995; accepted 28 April 1995. 